DE DE GRUYTER

OPEN

Polish Cartographical Review

Vol. 48, 2016, no. 4, pp. 185-196

DOI: $10.1515 /$ pcr-2016-0017

ANNA MAŁKA, WOJCIECH JEGLIŃSKI

Polish Geological Institute - National Research Institute

Marine Geology Branch in Gdańsk

Anna.Malka@pgi.gov.pl, Wojciech.Jeglinski@pgi.gov.pl

JUSTYNA RELISKO-RYBAK

Polish Geological Institute - National Research Institute

Pomeranian Branch in Szczecin

Justyna.Relisko-Rybak@pgi.gov.pl

\title{
Prussian geological maps of Northern Poland in the archives of the Polish Geological Institute and their current application in geology
}

\begin{abstract}
The article characterizes first general geological (lithological-stratigraphical) maps presenting Quaternary deposits in Northern Poland. These were the maps of territory of the Prussian partition, elaborated by German geologists from Prussian Geological Survey "Königlich Preussische Geologische Landesanstalt". After Poland regained its independence they became a basis for many Polish geological publications. The article discusses the chronology and objectives of the main cartographic works of German geologists operating in the area of present-day Northern Poland (general and detailed geological maps) and briefly presents the methodology of geological mapping of lowlands at the scale of 1:25,000.

The authors present initial results of the sheet inventory of the Prussian geological map at the scale of 1:25,000 owned by the Polish Geological Institute - National Research Institute (PGI-NRI). Quick search of Prussian map sheets is enabled with the created GIS data base which contains basic information about sheets, i.e. map title, year, author/authors, sheet title and topographic map designation. The applied relations between data and their spatial reference make it possible to dynamically generate section map and perform spatial analyses of any type. The multiuser geodatabase was created using ESRI and Oracle technologies. Until now the inventory covered the sheets available in the archives of the Marine Geology Branch of PGI-NRI in Gdańsk and the Pomeranian Branch of PGI-NRI in Szczecin.

The article also presents examples of Prussian topographic and geological maps used to realize the objectives of the surface geology of Poland. Sheets of Prussian maps are a very valuable basis for elaboration of general and detailed Polish geological maps. Prussian maps make it possible to recreate the earlier geological, geomorphological and hydrographic picture of terrains which are now highly developed and antropogenically transformed. They are often used for the purpose of various time-spatial analyses, mostly to evaluate the dynamics and pace of erosional and accumulative coastal processes of the Southern Baltic coast. The maps of this type help to reconstruct and forecast the development of river mouths and to recreate the location of excavations and inactive open-cut mines of sand, gravel, clay, brown coal and amber. Old maps documenting the exact location of exploited deposits have practical application in geo-tourism.
\end{abstract}

Keywords: geological maps, Prussian partition, 19th century, Northern Poland, young glacial area

\section{Introduction}

Geological maps are the most efficient form of projection of the geological structure of terrain surface. Elaboration of such maps is one of the basic tasks of all national geological surveys, both today and in the past. First geological maps were prepared in small scales by geology enthusiasts, doctors, lawyers, teachers, natu- ralists or even theologians. In the case of Polish territories, the oldest geological map is Carte Minéralogique de la Pologne at the scale of approximately $1: 4,400,000$ prepared by the French physician Jean-Etienne Guettard and published in 1764. The first Polish author of a geological map was a Catholic priest Stanisław Staszic, often referred to as "the father of Polish geology". His Carta geologica totius Polo- 
niae... at the scale of approximately $1: 1,250,000$ was attached to the publication titled $O$ ziemiorodztwie Karpatow $i$ innych gor i rownin Polski (On the Earthbearing of the Carpathians and Other Mountains and Lowlands of Poland) from 1815 (S. Wołkowicz et al. 2009).

In the late 18th century, after geology had been established as a separate discipline, the need for a detailed geological survey was formulated in western Europe (L. Lippstreu 2010). Because of the range and scale of such a geological survey it had to be financed by the state. In the case of then portioned Poland, comprehensive large scale cartographic projects relied on the needs and economic policies of the individual partitioning countries. They all had different concepts of spatial development, represented various levels of scientific progress and realized separate strategies concerning topographic and geological cartography. It should be stressed that the development of detailed geological cartography has always been conditioned by the development of topographic cartography, because the referential topographic base constitutes an inseparable part of each general and detailed geological map. Cartometric maps using measurements based on triangulation started to appear as early as in the first half of the 19th century. In comparison to the other partitioning powers, the Prussian state clearly led in innovation, level of detail and precision of trigonometric measurements (W. Jankowski 1961). In the 1820s the Prussian authorities ordered preparation of a, so-called, plane table map Urmesstischblätter at the scale of $1: 25,000$ made on the basis of a triangulation network (M. Jankowska 1993). For the area of today's Poland, about 1,200 sheets of this map had been prepared until 1876 (A. Konias 2010). However they were not published due to a large number of errors (K. Lindner 2003, after D. Lorek 2011). Measurements which had been carried out were later used in the 1860s for the map of the General Staff Generalstabkarte at the scale of 1:100,000 (M. Jankowska 1993). Basing on the updated Urmesstischblätter, more detailed topographic Messtischblätter at the scale of 1:25,000, with pristine terrain presentation, were published between 1875 and 1930. Achievements of Prussian cartography in the area of topographic maps which were the base for all thematic presentations, provided excellent backing for Prussian geological cartography. Both Generalstabkarte sheets at the scale of $1: 100,000$ and Messtischblätter sheets at the scale of 1:25,000 served as reference base for Prussian geological maps.

Detailed characteristics, conditions of development, preparation methods, contents and precision of Prussian topographic maps have been presented in many publications, among others in works of M. Jankowska (1993), A. Konias (2010) and D. Lorek (2011). The 19th century geological cartography of Polish territories, including large scale geological maps and detailed geological maps of mountain regions (most prospective for mineral deposits) as well as achievements of Polish geologists at the times of partitioning is discussed by B. Kosmowska-Ceranowicz (1968), M. Graniczny et al. (2006, 2007), H. Urban and M. Graniczny (2009), S. Wołkowicz et al. (2009) and A.J. Wójcik (2013).

Achievements of Polish geological cartography in the period between the World Wars was researched by E. Rühle $(1949,1972)$ and J. Skoczylas (2009). Historical review of the development of geological studies in Poland was presented by, among others, A.J. Wójcik (1992, 2011) and J. Miecznik (2013). However, until today there has not been any analogical research on Prussian geological maps of the 19 th and early 20th centuries which covers the young glacial area of Northern Poland, i.e. the belt of coastal plains and lake districts shaped by the continental glacier of the last glaciation period $^{1}$. In the 1950 s a query of Polish and Prussian cartographic materials for the whole area of Poland was conducted and published in the form of a bibliography (M. Sokołowska 1954, I. Gałecka et al. 1956). Those works concerning Prussian maps were later not verified ${ }^{2}$ and unfortunately not continued, although that had been the initial intention of the authors of the catalogue. They were aware of the significance of updating the registry of geological maps as new data becomes available.

\footnotetext{
1 The geographic area of Northern Poland assumed in the work covers, according to J. Kondracki's physico-geographical division (1989) the following sub-provinces: South-Baltic Coastal Plains, East-Baltic Coastal Plains, South-Baltic Lake Districts, East-Baltic Lake Districts. The boundaries of that area have been presented further in the article (fig. 2).

2 Bibliografia i rejestr map... by I. Gałecka et al. (1956) contains mistakes pertaining to e.g. the naming of Prussian maps.
} 
Currently, bibliographic work on old geological cartography using GIS technology is done by the Polish Geological Institute - National Research Institute (PGI-NRI). Recently, activities aiming at an inventory of the scattered collection of archival old serial maps - sheets of the Prussian geological map at the scale of $1: 25,000$ belonging to $\mathrm{PGI}-\mathrm{NRI}$ have been started. A base of GIS data containing sheet information (in analog and digital versions) was created first. The database contains basic information on sheets, i.e. map title, the year of publication, the author (or authors), the title of the geological map sheet, the title of the topographic map sheet (not always the same as for the geological map) and the topographic map designation. Applied relations and spatial reference make it possible to dynamically build section maps and perform spatial analyses of any type. The multiuser geodatabase was created using ESRI and Oracle technologies. Until now, the inventory has covered the sheets available in the archives of the Marine Geology Branch (MGB) of PGI-NRI and the Pomeranian Branch (PB) of PGI-NRI in Szczecin. Future works will be extended to include collections of the remaining PGI-NRI branches and other institutions (libraries and archives). This article contains the initial results of the query and research. It also characterizes the first general geological (lithological-stratigraphical) maps presenting Quaternary deposits in Northern Poland. These maps were elaborated by highly qualified specialists from the Prussian Geological Survey. After Poland had regained its independence they became a basis for many Polish geological publications. The article discusses the chronology and objectives of the main cartographic work of Prussian geologists operating in the area of today's Northern Poland (general and detailed geological maps) and briefly presents the methodology of geological mapping of lowlands at the scale of $1: 25,000$.

Old Prussian geological maps, mostly at the scale of $1: 25,000$, were used by Polish geologists, especially after World War II. Also today they provide a valuable source of geological information which is often impossible to obtain through other methods, e.g. because of strong antropogenic transformation of the studied area. The archives of the Polish Geological Institute contains extensive collections of these maps. On the following pages the authors present examples of using Prussian topographic and geological maps to accomplish the objectives of Polish surface geology.

\section{General Prussian geological maps}

The multi-sheet Geologische Karte der Provinz Preussen (Geological Map of the Prussia Province - GMPP) at the scale of $1: 100,000^{3}$ (fig. 1) was the first geological map prepared on the basis of field geological mapping showing Quaternary deposits in today's Northern Poland. In was made in the second half of 19th century to an order from the Royal Physico-Economic Society of Königsberg (today's Kaliningrad). Its topographic base consisted of the most current sheets of topographic maps, including the sheets of the Map of the General Staff at the scale of 1:100,000. The Geological Map of the Prussia Province was the second map in Europe to present Quaternary deposits and stratigraphy of Pleistocene and Holocene deposits, earlier referred to as diluvial and alluvial deposits (P. Schiefferdecker et al. 1870). In total 41 sheets of this map were planned, covering mainly the Eastern part of today's Northern Poland and the Western part of today's Lithuania and Russia (fig. 1, G. Berendt 1866). From 1865 to 1879, 17 sheets of GMPP were prepared in total, of which 15 had been prepared before 1887 (A. Jentzsch 1887). The author of as many as 12 sheets was Gottlieb Michael Berendt, an outstanding Prussian geologist of the Quaternary and a cartographer. He got a professorship at the University in Königsberg and at the Mining Academy in Berlin (Bergakademie), and one of the first geologists who studied the geological structure of lowland areas. Field geological work during the elaboration of GMPP gave him a lot of experience in geological mapping. Because of the qualifications achieved this way he was given the task of regional coordination of work on the geological and soil map at the scale of $1: 25,000$ in the lowland areas of the Prussian state of that time.

Work on the series of the first multi-sheet general geological map at the scale of $1: 100,000$

\footnotetext{
${ }^{3}$ In the Kingdom of Prussia, the first official geological maps (scale 1:100,000 and 1:80,000) were made and published to an order from the Ministry of Commerce, Craft and Public Works for the region of Rhineland between 1855 and 1865 , and between 1861 and 1863 for the region of Lower Silesia (L. Lippstreu 2000).
} 


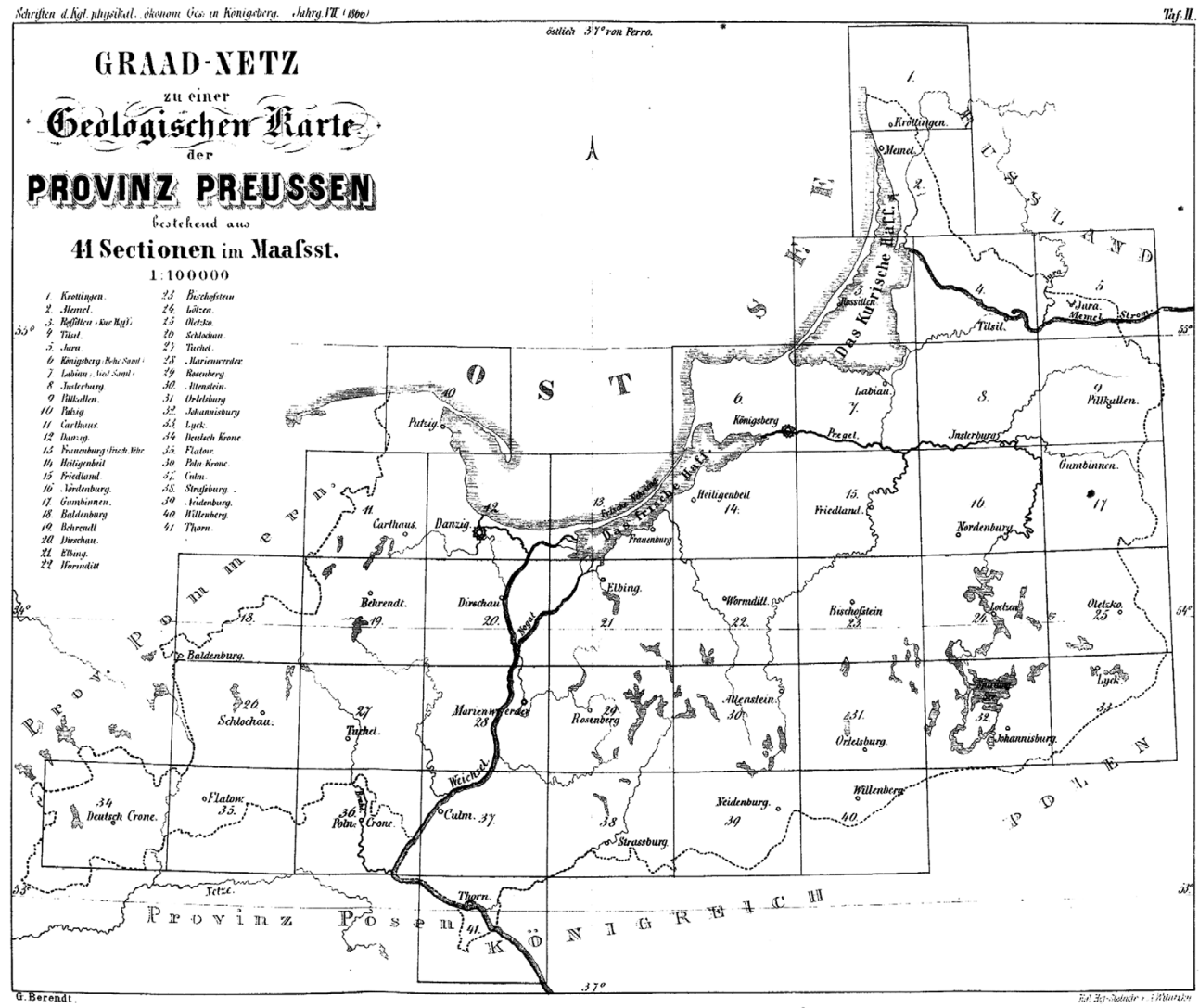

Fig. 1. Section map of planned sheets of the Geological Map of the Prussia Province at the scale of 1:100,000 (G.M. Berendt 1866)

was never completed. The main reason was the necessity of elaboration of a series of detailed geological and soil maps at the scale of 1:25,000 which would be used in Prussian economy (mainly in agriculture, forestry, the infrastructure system). Although after reaching a certain stage of geological field works at the scale of $1: 25,000$, continuation of the publication of GMPP was planned, the political-economic consequences of the begin of First-World War verified these plans; as a result not all planned sheets of the MGPP were finished. Currently the early achievements of Prussian geological cartography on the territories of today's Poland is practically unknown.

Prussian Geological Survey was founded in 1873. Its main tasks were to determine the geological foundation of the Prussian state and to prepare geological cartographic presentations of it. Within these tasks general geological maps of lowlands at the scale of 1:200,000, $1: 300,000$ and $1: 500,000$ were elaborated. Many sheets of those maps were prepared by another outstanding Prussian geologist, Konrad Keilhack, who also had significant experience in the area of detailed geological cartography ${ }^{4}$. A general map at the scale of 1:500,000, covering most of today's Zachodniopomorskie

\footnotetext{
${ }^{4} \mathrm{~K}$. Keilhack prepared over one hundred sheets of the Prussian geological map at the scale of 1:25,000, together with commentaries (http://www.deutsche-biographie.de/). He also proposed the names for the three main glacial levels Elster, Saale and Weichsel, which are still used today in Central Europe (W. Stackenbrandt 2005). The last name, which is the name of the most recent Pleistocene ice age the glaciation of the Vistula river (Weichsel) has been accepted also in Poland.
} 
voivodship (West Pomeranian), is an example of his work. The first edition was published in 1896, and in 1930 Keilhack updated it with results of more recent research (K. Keilhack 1930).

\section{Detailed Prussian geological maps at the scale of $1: 25,000$}

The development of Prussian geological cartography was strongly stimulated by the introduction of the 1:25,000 topographic map as the basis for geological mapping. In 1862 it was decided that geological-cartographic field research at the scale of 1:25,000 would cover the whole area of Prussia. Ernst Beyrich was nominated as the main coordinator of the project; he also became the first scientific director of the Prussian Geological Survey. Elaboration of detailed geological maps of lowland areas at the scale of $1: 25,000$ were started a year after the Prussian Geological Survey had been founded (L. Lippstreu 2000). It should be stressed that in the 19th century it was one of the better developing scientific research institutions on the European continent. Very detailed geological maps were published in the Kingdom of Prussia, standards of geological mapping later adopted not only in German speaking countries, but in all Europe, were also created there. Acknowledgment of the theory of glaciation had a significant impact on the development of geological cartography of lowland areas ${ }^{5}$. The Swedish geologist Otto Torell, who in 1875 noted glacial stria on an erratic boulder in Rüdersdorf, south of Berlin, had a direct influence on the reception of the theory in Central Europe (L. Lippstreu 2000; W. Stackebrandt 2005). One of the wit-

\footnotetext{
5 The history of research of the formation of glaciers and ice sheets in the geological past started at the beginning of the 19th century and was accepted not without objections by the adherents of Lyell's iceberg drift theory (L. Lippstreu 2000). Between 1901 and 1909, on the basis of research in the Alps and Pyrenees, Eduard Brückner and Albrecht Penck distinguished four main ice ages: Günz, Mindell, Riss and Würm (A. Wójcik 2011). The Ice Age theory developed in the years $1820-1840$. Its authors include the Swiss geologists I. Venetz, J. Charpentier and L. Agassiz (R. Grapes et al. 2008). In 1840, the Swiss-American geologist L. Agassiz (sometimes referred to as the father of glaciology) announced in his most recognized work Etudes sur les glaciers that in the Ice Age ice covered most of today's Europe (https://www.britannica.com). Among the proponents of this theory were P. Kropotkin, F.B. Schmidt and O. Torell. The latter put forward the most convincing arguments for the conceptualization of ice age in northern Eurasia (R. Grapes et al. 2008).
}

nesses of that discovery, groundbreaking for the geology of the Quaternary, was G.M. Berendt, the head editor of GMPP, who also played a key role in the development of detailed geological mapping of lowland areas in the Prussian state of that time. He acted as a regional coordinator, carried out field topographic mapping and authored many sheets of the Prussian Geological Map (PGM) at the scale of $1: 25,000$. He was also the author of the methodology of geological mapping in lowland areas which is still valid today. As soon as in 1874 he introduced into geological cartography the practice of documenting the geological structure to the depth of 2 meters using hand held rock drillings (Pürckhauer-Bohrer) ${ }^{6}$. Berendt was the author of the first commentaries to the pilot sheets of the geological map of the Berlin area at the scale of $1: 25,000$. They became a model for the future geological cartographic studies. This outstanding Prussian researcher also created the colour scale for Pleistocene and Holocene deposits (O. Wagenbreth 1999, L. Lippstreu 2000).

The first field geological works at the scale of $1: 25,000$ for lowland areas shaped by the last glaciations were started in 1874. Because of public interest in the area of agriculture and forestry geological cartography was at that time connected to soil cartography. Such hybrid geological-soil maps had been published until the first half of the 20th century when the combined dual-component methodology was abandoned. Sheets of the Prussian geological-soil map at the scale of 1:25,000 are a source of detailed information on geological structure. They present the stratigraphy of geological formations, its lithological composition, the parent material of soils, layer sequence in the soil profile to the depth of two meters, mines and location of hand held and mechanical rock drills. Individual sheets are accompanied with explanations which describe the geological structure of the areas covered, present profiles of major boreholes, and included results of field research and laboratory analyses.

The Prussian geological map at the scale of $1: 25,000$ changed its title and form several times in the 19th century and at the beginning of

\footnotetext{
${ }^{6}$ This method is still satisfactorily used today in geological field works in lowland regions. It facilitates the creation of a surface geological map as well as the documentation of lithological sediment changeability (A. Marks, A. Ber 1999).
} 


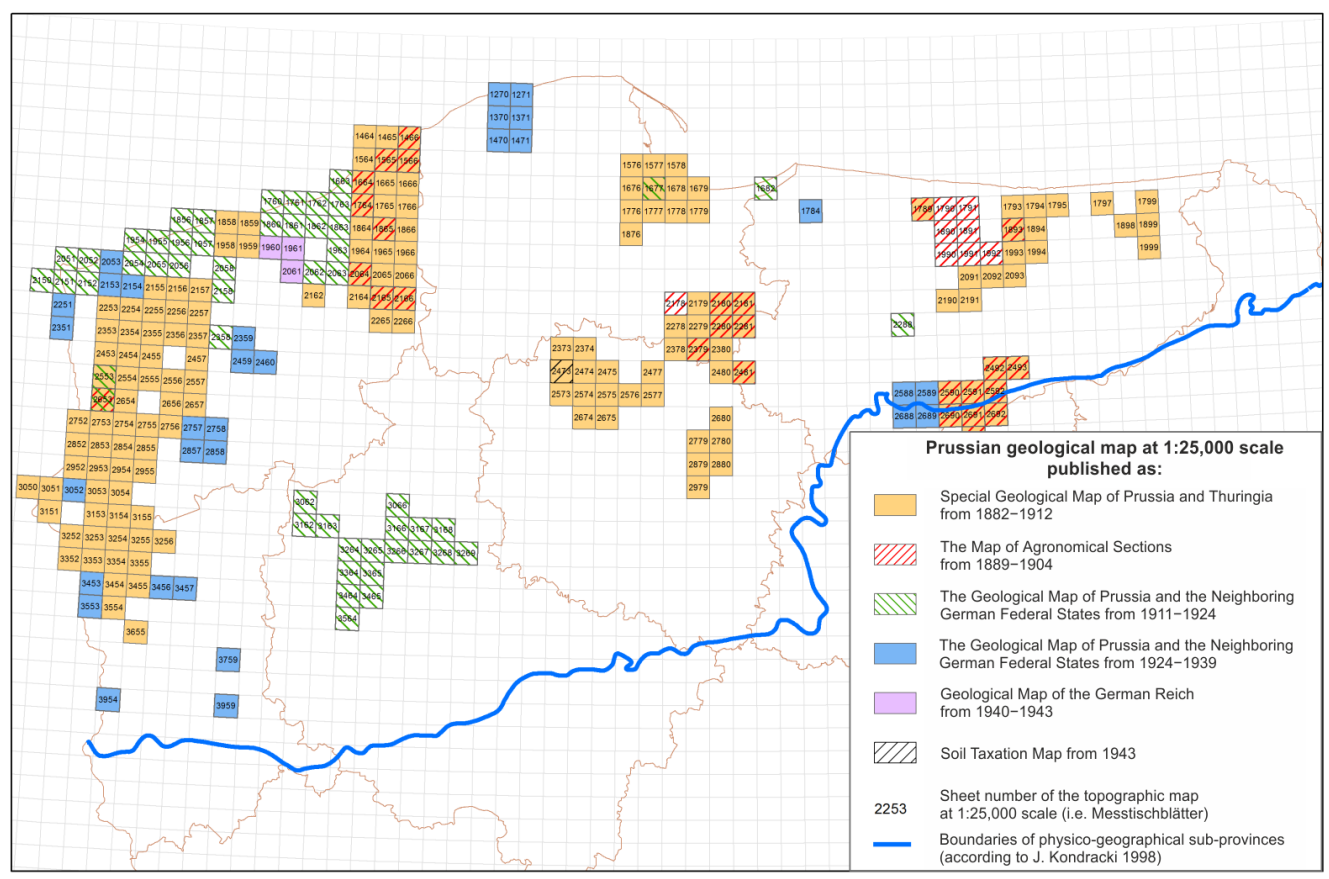

Fig. 2. Section map and age structure of the Prussian geological map at the scale of 1:25,000 of the area of Northern Poland from the collection of MGB and PB PGI-NRI

the 20th century. Also the authority which elaborated and published the geological maps was renamed (L. Lippstreu 2000, 2003). Currently the collection of MGB and PB of PGI-NRI includes 377 sheets of the Prussian geological map at the scale of $1: 25,000$. The section map and age structure for the map of Northern Poland is presented in figure 2.

The first published map of the series was the Geologische Spezialkarte von Preußen und den Thüringischen Staaten (Special Geological Map of Prussia and Thuringia) prepared and published by the geological survey which at the time was referred to as the Königlich Preußische Geologische Landesanstalt und Bergakademie (Royal Prussian Geological Survey and Mining Academy). 162 sheets preserved in the collection were published in Berlin between 1882 and 1912. The legend of the map includes geological descriptions ${ }^{7}$ of simple individual

\footnotetext{
${ }^{7}$ Archaically referred to on the special geological map of Prussia and Thuringia as geo-gnostic (geognostisch) explanations - http://sjp.pwn.pl/doroszewski/
}

litostratigraphical units, like upper or lower till unit, as well as detailed descriptions of soil units $^{8}$ - soil parent material. The map Agronomische Bohrungen (The Map of Agronomical Sections) was an inseparable part of the publication. Currently the collection of MGB and PB PGI-NRI includes 35 sheets of this map, published from 1889 to 1904 . Later the printing was abandoned - the map was only available on request at Prussian Geological Survey.

The next map of the series, published by the Prussian Geological Survey, was the Geologische Karte von Preußen und benachbarten Bundesstaaten (The Geological Map of Prussia and the Neighboring German Federal States). Currently the collection of MGB and PB PGI$\mathrm{NRI}$ includes 91 sheets of this map, published from 1911 to 1924 . The legend did not include separate geological and soil commentary, which improved clarity. In 1919, after the fall of the Prussian monarchy, the Royal Prussian Geo-

\footnotetext{
${ }^{8}$ On the special geological map of Prussia and Thuringia, there appears the term "agronomical" (agronomisch).
} 
logical Survey was renamed the Preußische Geologische Landesanstalt (Prussian State Geological Survey). Between 1924 and 1939 the map was published under a slightly changed name - the Geologische Karte von Preußen und benachbarten deutschen Ländern (The Geological Map of Prussia and the Neighboring German Federal States). However, the map system remained unchanged. 72 sheets from that period are in the archives of MGB and PB PGI-NRI.

In 1939 the Prussian and Austrian Geological Surveys merged, which resulted in the foundation of the Reich Office for Scientific Soil Research (Reichsstelle für Bodenforschung). The map changed its name once again into the Geologische Karte des Deutschen Reiches (Geological Map of the German Reich). 16 sheets of this map are in the collection of MGB and PB PGI-NRI.

At the same time Bodenschätzungkarte (Soil Taxation Map) became a product category. In the archives of MGB and PB PGI-NRI there is a single example of such maps - Tuchola sheet from 1943.

Registries of drilling included in the reports from the core archive ("Mitteilungen aus dem Bohrarchiv") is a valuable supplement to the Prussian geological and soil map. Prussian geological maps, especially Gdańsk, Wisłoujście with Nowy Port and Oliwa sheets (O. Zeise 1903a,b,c; O. Zeise, W. Wolff 1916) and the drilling data were later used in the preparation of the map of building conditions in the Gdańsk area at the scale of $1: 10,000$ ( $E$. Moldenhauer 1921).

\section{Examples of application of Prussian geological and topographic maps in Polish geological publications}

Prussian geological and topographic maps covering the area of Poland under the former partition were, and still are used to accomplish objectives in the field of geology and geomorphology. After Second-World War Polish geology faced an important task, which was to prepare a uniform geological map of the whole state (E. Rühle 1984). Between 1947 and 1953, in sum 28 sheets of the Przeglądowa mapa geologiczna Polski (General Geological Map of Poland) at the scale of 1:300,000 were edited by a team led by Edward Rühle. Each sheet consisted of edition A - Mapa utworów po- wierzchniowych (Map of Quaternary deposits) and B - Mapa bez utworów czwartorzędowych (Map without Quaternary deposits).

In 1960 there appeared a concept of editing a new multi-sheet Mapa geologiczna Polski (Geological map of Poland) at the scale of $1: 200,000$. The need for such publication resulted from intensive development of geology, increase in the number of drilling profiles and improved knowledge of geological structure of particular regions of Poland. Between 1968 and 1998, 77 sheets of the map edited by Józef Edward Mojski were published in the same double editions as before: $A$ - Map of Quaternary deposits and $B$ - Map without Quaternary deposits.

In both cases sheets of the German maps at the scale of $1: 200,000$ and $1: 500,000$ provided an extremely valuable basic material for the elaboration of general Polish geological maps. Detailed Prussian geological maps at the scale of 1:25,000 were used mainly during the editing process of the Szczegółowa mapa geologiczna Polski (Detailed Geological Map of Poland DGMP) at the scale of 1:50,000, which was one of the main tasks of the Polish Geological Institute - National Research Institute (PGI-NRI).

The years 1954-1960 are considered to be the beginning of elaboration of DGMP (A. Makowska 1997). Initially it was to consist of 1069 sheets at the scale of 1:50,000, 44 of which, covering the area of Sudetes mountains, were to be prepared at the scale of $1: 25,000$. The first sheets for the area of Northern Poland were prepared by combining German maps, e.g. Białogard sheet (author S. Tyski, 1960) or by upgrading on the basis of German maps, e.g. Polanów sheet (author J.E. Mojski, 1959). Because of different scales and methodologies of preparation of Prussian geological and soil maps and DGMP, the authors had to reinterpret geological data. Nevertheless the analysis of individual sheets shows high conformity in both unit borders and lithological characteristics. Small differences are mainly due to map scales and resulting generalization. Differences in terminology visible on maps are caused by development of science, e.g. terms diluvial and alluvial deposits are old names for the Holocene and Pleistocene. Apart from that, on the Polish map unit descriptions are of lithogenetic character, while on the Prussian map lithological (fig. 3). 

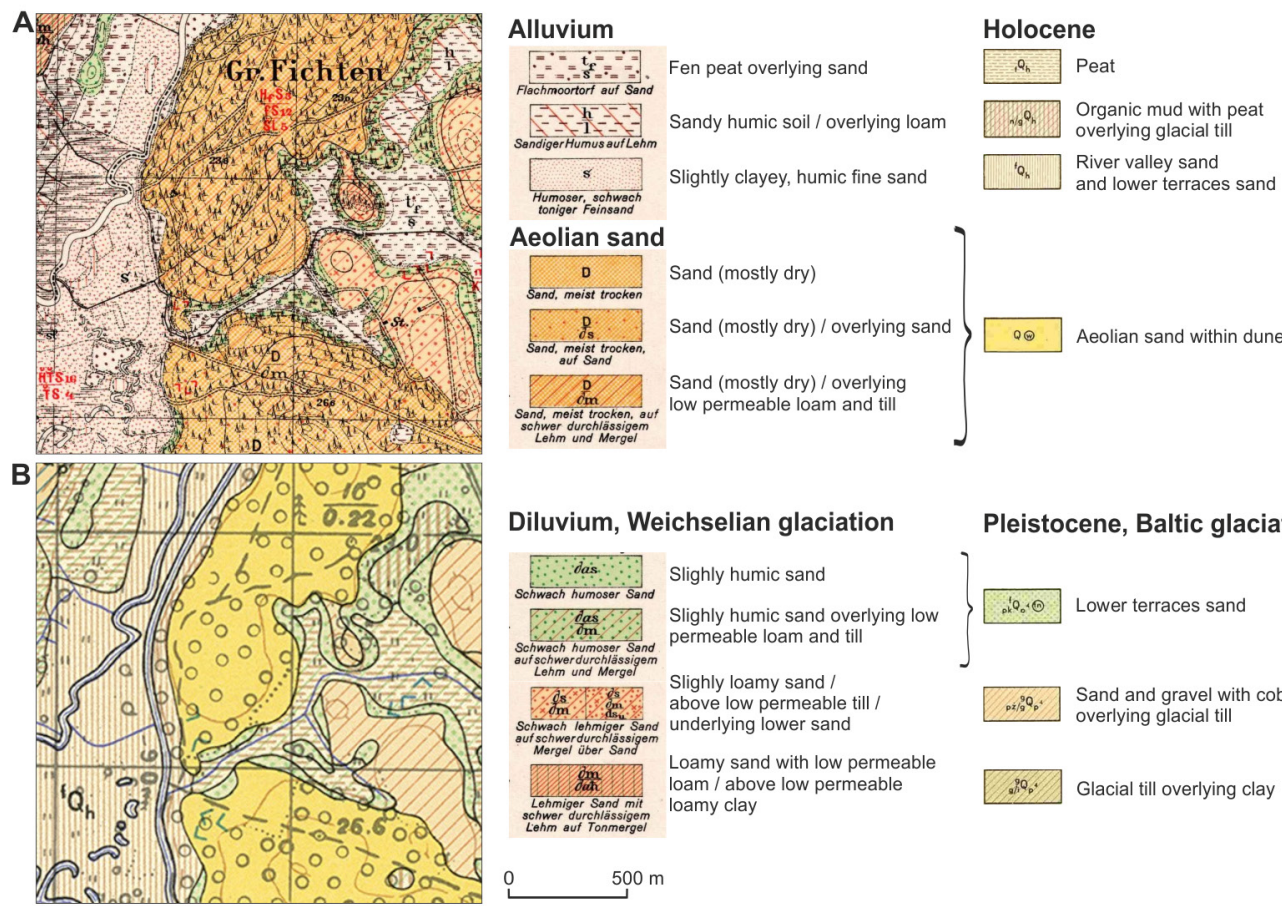

Aeolian sand
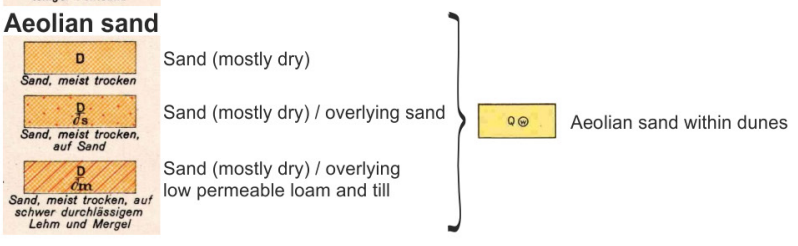

Diluvium, Weichselian glaciation

Pleistocene, Baltic glaciation
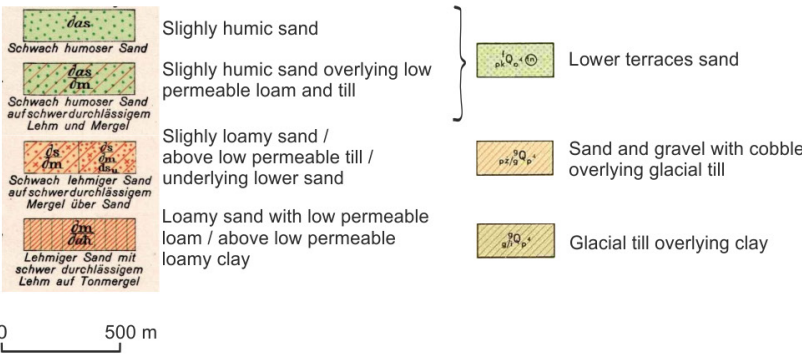

Fig. 3. Parts of geological map, Białogard sheet: A - Geologische Karte des Deutschen Reiches - Belgard at the scale of 1:25,000 (reduced to 1:50,000), B - Szczegółowa mapa geologiczna Polski

(Detailed Geological Map of Poland) at the scale of 1:50,000

Today, despite the development of research and outdated old stratigraphic divisions, Prussian maps still provide valuable comparative material, also during the updating of DGMP, because of their high level of detail, clarity, precision and high quality.

Prussian maps, and especially sheets of the Geological Map of the Prussia Province at the scale of 1:100,000 (A. Małka 2012) and sheets of topographic maps at the scale of 1:25,000, mainly Urmesstischblätter, make it possibile to recreate the location of former excavations and inactive open-cut mines of sand, gravel, clay, brown coal and amber. Old maps documenting the precise location of exploited deposits have practical application in geo-tourism as unique, historical cartographic materials showing cultural heritage. Analyses of historical cartographic materials make it easier to select geosites and prepare visually attractive popular-scientific folders, charts and geo-touristic maps. Former mines of Baltic amber are a good example. Detailed analysis of archival cartographic material allowed not only to determine their precise locations, but also to determine new, so far unknown ${ }^{9}$ places of extraction of this valuable resource (A. Małka 2015a,b). Fragments of Prussian maps presenting old amber mines were placed on tourist boards in "Bursztynowa Góra" (Amber Mountain) reserve of inanimate nature in Bąków near Gdańsk and in Świńcz near Pruszcz Gdański.

The foregoing maps make it possible also to recreate the historical geological, geomorpho-

\footnotetext{
9 Up to now (data from December 2016), in the Pomorskie Voivodship alone, 33 as yet unknown Baltic amber excavation sites have been marked on the basis of the analysis of Prussian topographic and geological maps and historical materials. In total, there are 78 known old amber mines in the Pomorskie Voivodship, at least five of which are very attractive from the point of view of geo-tourism. Most of them, unfortunately, are not accommodated to receive tourists. There are plans to broaden the scope of research to the whole territory of Poland and to take into account in the analysis previously unknown or unused archive materials, including the Polish Military Geographic Institute maps at the scale of 1:100,000.
} 
logic and hydrographic picture of the terrain which is now highly developed and antropogenically transformed. This refers mainly to 1960s (M. Lidzbarski et al. 2014). As a result, in the 20th century significant lowering of the groundwater table and drying of the terrain took
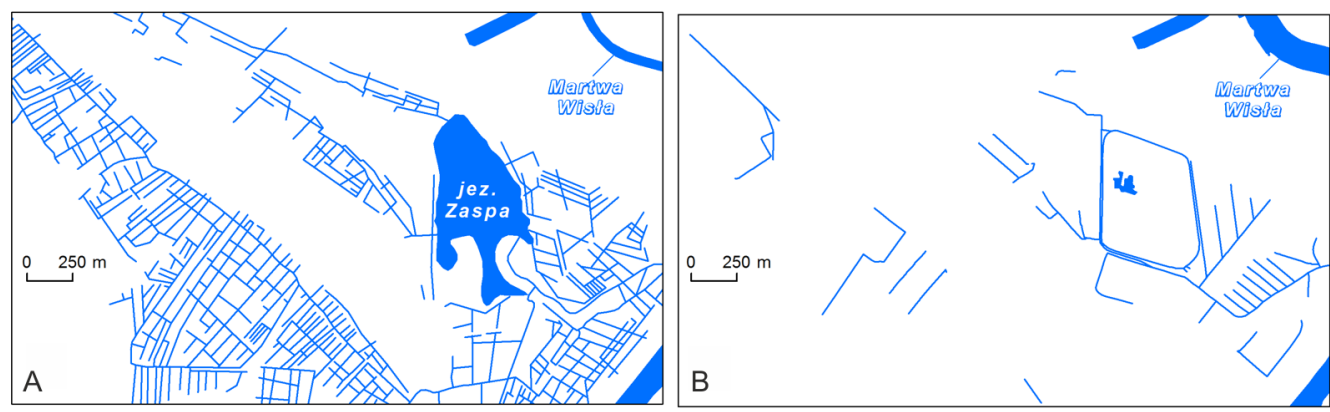

Fig. 4. Water network of a low located fragment of the city of Gdańsk: $A$ - at the end of the 19th century, recreated according to Messtischblätter topographic map at the scale of 1:25,000, B - current state according to the Mapa podziału hydrograficznego Polski (Map of hydrographic division of Poland) at the scale of 1:10,000

dynamically developing city areas, where the "original" character of surface has been almost erased, and where new research is difficult to conduct. In the case of Gdańsk (fig. 4) changes of surface waters over the last 100 years have been immense, e.g. disappearance of the old Zaspa lake and the system of drainage ditches. Significant drying of terrain should be connected to the exploitation of "Zaspa" and "Czarny Dwór" groundwater captures and dehydration of the area. "Zaspa" groundwater intake was built in 1914, while "Czarny Dwór" was built in place. Additionally, after 1945 the disappearance of the lake was also accelerated by filling it in with rubble from the ruined city. In 1970s, after the lake became the property of the Gdańsk heat and power station, it became a dumping ground for furnace waste (http:// www.trojmiasto.pl/). The example of Zaspa lake disappearance clearly demonstrates how useful old Prussian maps can be for analysis of changes in water network.

Prussian topographic maps are also readily used, among others, for various time-spatial

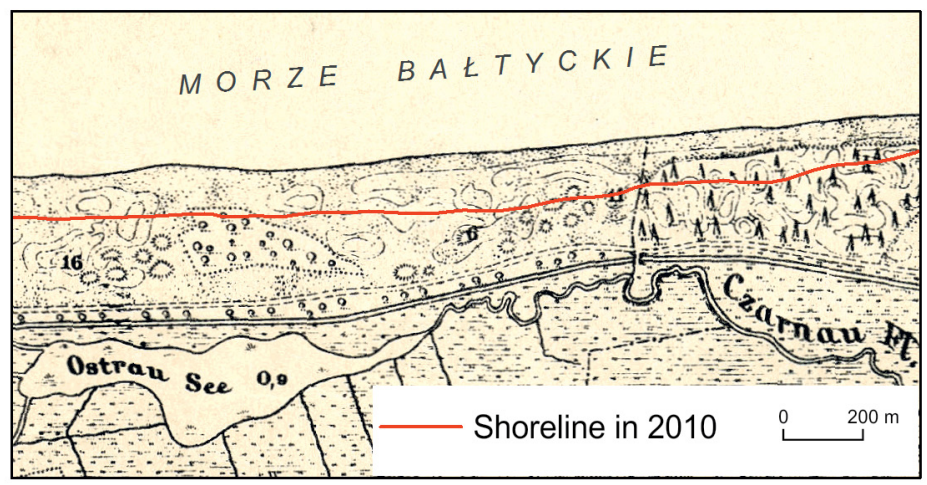

Fig. 5. Fragment of the Ostrau sheet of Messtischblätter topographic map at the scale of 1:25,000 presenting the sea coast between Jastrzębia Góra and Karwia (134.7-137 km); dislocation (withdrawal) of the coastline resulting from the erosion action of the sea, occasionally reaches approximately $150 \mathrm{~m}$ 
analyses, especially to evaluate dynamics and pace of erosional and accumulative coastal processes of the South coast of the Baltic Sea (E. Zawadzka-Kahlau 1999; G. Uścinowicz et al. 2014, fig. 5). Maps of this type help to reconstruct and forecast the development of river mouths, especially those located within the Vistula delta (D. Koszka-Maroń, W. Jegliński 2009; W. Jegliński 2013).

\section{Conclusions}

Prussian geological maps of the area of Northern Poland have been a valuable source of both geological and historical information, and they are readily used by the staff of PGI-NRI during completing of current tasks in the field of widely understood geological cartography.

The archives of PGI-NRI contain digital and analogue sheets of Prussian topographic, geological, geological-agronomical and agronomical maps, as well as explanatory texts to accompany the geological maps and geological cross-sections from the 19th and early 20th centuries. PGI-NRI collection also contains maps showing locations of boreholes drilled for the purpose of Prussian geological maps and instructions for preparation of topographic and geological maps ${ }^{10}$. The inventory works to date have comprised the archives of MGB PGI-NRI in Gdańsk and the PB PGI-NRI in Szczecin. In the remaining PGI-NRI archives, there are sheets of the Prussian geological map at the scale of $1: 25,000$ (mainly in paper form). However, the collection is scattered and not fully catalogued, which makes it difficult to estimate the size of the PGI-NRI collection. Inventory works will be gradually continued, and the formed GIS data base continually revised so that it finally includes all the Prussian geological maps at the scale of 1:25,000 which can be found in the PGI-NRI archives. In the future, the catalogue of Prussian geological maps in the form of a data base will be thoroughly compared with the register of maps published in 1950s (M. Sokołowska 1954, I. Gałecka et al. 1956). Sketchy analysis of the 1950s register and MGB and PB of PGI-NRI datebase indi-

\footnotetext{
${ }^{10}$ In 2013, the archives of PGI-NRI were enriched by the purchase of 225 sheets of maps from the territory of Poland and the Sambia Peninsula (Russia) from the collection of Mr. Dirk Schümann
}

cates to sheets found in Gałecka register, which are not to found in the PGI-NRI datebase. Similarly, the PGI-NRI datebase contains sheets which are not included in the Gałecka bibliography. In the next stage, German catalogues and publications made in 1950s will be used in the GIS data base to show the sheets which have been done by Prussian geologists and are absent from the PGI-NRI archives. Future work also comprises providing a map service that would feature an interactive section map of sheets together with meta-information as well as map contents, which requires scanning and geo-adjustment of individual sheets in order to obtain their digital image in GIS environment ${ }^{11}$. Prussian cartographic elaborations of the area of Poland are available on the Internet (e.g. http://www.staremapy.org/, http://mapy.amzp.pl/, http://www.mapy.eksploracja.pl/, http://www.davidrumsey.com/). However, these are mainly topographic maps. A geoportal fully devoted to Prussian geological cartography of the area of Poland will facilitate the search for past geological data, and a general, participative access to such a service may enlarge the collection. Eventually all the old Prussian geological maps from the region of Poland will be easily accessible on the internet in one easily found place. The maps can be used for cartographic elaborations and scientific research in various complex ways. High contents and esthetic value as well as clarity of Prussian geological maps can serve as an inspiration and model for future research.

\section{Acknowledgments}

The authors would like to thank the anonymous reviewers for their helpful and constructive comments that greatly contributed to improving the final version of the paper. They would also like to thank the Editors for their generous comments and support during the review process. Finally, they would like thank dr Andreas Börner (Landesamt für Umwelt, Naturschutz und Geologie Mecklenburg-Vorpommern) and Adam Trubłajewicz for help with translation.

\footnotetext{
${ }^{11}$ Polish Geological Institute - NRI through GeoLOG website currently gives access to rectified old maps, i.e. geological maps of S. Staszic, J.B. Pusch and G. Blöde from the early 19 th century (http://geoportal.pgi.gov.pl/).
} 


\section{Literature}

Berendt G., 1865, Bericht an die Königl. Physikalisch-Ökonomischen Gesellschaft zu Königsberg über die geognostischen Kartenaufnahmen des Jahres 1865 innerhalb der Provinz Preußen. „Schriften der Königlichen Physikalisch-Ökonomischen Gesellschaft" Königsberg, Bd. 6. Beilage A, pp. 6-12.

Berendt G., 1866, Vorbemerkungen zur geologischen Karte der Provinz Preussen. „Schriften der Königlichen Physikalisch-Ökonomischen Gesellschaft" Königsberg, Bd. 7, pp. 71-80.

Gałecka I., Kaczkowska Z., Kalniet A., Sokołowska M., 1956, Bibliografia i rejestr map oraz materiałów kartograficznych z zakresu geologii Polski. Wiek XIX i XX. Warszawa: Wydawnictwa Geologiczne.

Graniczny M., Kacprzak J., Urban H., 2006, Mapy geologiczne i opisy ziem polskich w XVIII i pierwszej połowie XIX wieku. „Przegląd Geologiczny” T. 54, nr 9, pp. 759-763.

Graniczny M., Kacprzak J., Urban H., Wołkowicz S., 2007, Atlas Geologiczny Galicyi - pierwsza seryjna edycja map geologicznych ziem polskich. „Przegląd Geologiczny” T. 55, nr 5, pp. 368-372.

Grapes R.H., Oldroyd D.R., Grigelis, 2008, History of Geomorphology and Quaternary Geology. London: The Geological Society.

Jankowska M., 1993, Okoliczności powstania i sposób opracowania pruskiej mapy topograficznej z I połowy XIX wieku w skali 1:25 000. „Roczniki Akademii Rolniczej w Poznaniu” 240, pp. 37-45.

Jankowski W., 1961, Niemiecka mapa w skali 1:25000 na terenach polskich na wschód od Odry i Nysy. „Przegląd Geodezyjny” R. 32, nr 11, pp. 417-422, nr 12, pp. 458-462.

Jegliński W., 2013, Rozwój wybrzeża Zatoki Gdańskiej w rejonie ujścia Martwej Wisły. „Przegląd Geologiczny” T. 61, nr 10, pp. 587-595.

Jentzsch A., 1887, Über den neuesten Stand der geologischen Kartierung Preußen, „Schriften der Königlichen Physikalisch-Ökonomischen Gesellschaft" Königsberg, Bd. 28, p. 17.

Keilhack K., 1930, Vorlegung einer neuen geologischen Übersichtskarte der Provinz Pommern. „Zeitschrift der Deutschen Geologischen Gesellschaft" Bd. 82, 1930, p. 125.

Konias A., 2010, Kartografia topograficzna państwa i zaboru pruskiego od II połowy XVIII wieku do połowy XX wieku. Słupsk: Wydawnictwo Naukowe Akademii Pomorskiej w Słupsku.

Kosmowska-Ceranowicz B., 1968, Polska kartografia geologiczna przed 1919 r. Katalog wystawy. Preface A. Halicka. Warszawa: Muzeum Ziemi PAN, Wydawnictwa Geologiczne, 73 pp.

Koszka-Maroń D., Jegliński W., 2009, Development of the Vistula river mouth fan. „Zeitschrift der Gesellschaft für Geowissenschaften", pp. 137-141.
Lidzbarski M., Karwik A., Kordalski Z., Pasierowska B., Sokołowski K., Szelewicka A., Tarnawska E., 2014, Szczegółowa ocena zasięgu i rodzaju zanieczyszczeń w wodach podziemnych na wybranych obszarach zurbanizowanych i poprzemysłowych na terenie Gdańska. Gdańsk: PIG-PIB. Typescript.

Lippstreu L. 2000, Von den Anfangen der geologischen Kartierung im ehemaligen Preußen - ein Beitrag zum Beginn der geologisch-agronomischen Kartierung im Norddeutschen Flachland vor 125 Jahren. „Brandenburgische Geowissenschaftliche Beitrage" 1/2, pp. 5-19.

Lippstreu L. 2003, Die geologische Karte von Preussen im Massstab 1:25 000 jetzt auch auf $C D$. „Brandenburgische Geowissenschaftliche Beitrage" 1/2, pp.195-197.

Lorek D.J., 2011, Potencjał informacyjny map topograficznych Urmesstischblätter z lat 1822-1833 z terenu Wielkopolski. Poznań: Uniwersytet im. Adama Mickiewicza, $132 \mathrm{pp}$.

Makowska A., 1997, Początki redakcji Szczegółowej mapy geologicznej Polski w skali 1:50 000. „Przegląd Geologiczny” T. 45, nr 2, pp. 197-200.

Małka A., 2012, Eksploatacja surowca bursztynowego z nagromadzeń czwartorzędowych w okolicach Gdańska w XIX i na początku XX wieku. „Prace Muzeum Ziemi" Nr 50, pp. 45-56.

Małka A., 2015a, Geostanowisko powydobywcze „Bursztynowe Kule”. „Bursztynisko” Nr 37, pp. 9-11.

Małka A., 2015b, Śladami bursztynowego górnictwa w województwie pomorskim. „Acta Universitatis Lodziensis. Folia Geographica Socio-Oeconomica" Nr 22, Geografia historyczna \& HGIS. Łódź, pp. 65-86.

Marks L., Ber A., 1999, Metodyka opracowania Szczegółowej mapy geologicznej Polski w skali 1:50 000. Warszawa: Państwowy Instytut Geologiczny, 90 pp..

Miecznik J.B., 2013, Na wyżynach polskiej geologii. „Przegląd Geologiczny” T. 61, nr 11/2, pp. 683-689.

Mojski J.E., 1989, Mapa geologiczna Polski w skali 1:200 000. „Kwartalnik Geologiczny” T. 33, nr 1, pp. 73-80.

Moldenhauer E., 1921, Die Ausgestaltung der historisch-geologischen Karte des Danziger Stadtgebiets zu einer technisch-geologischen. Halle (Saale): Verlag von Wilhelm Knapp.

Rühle E., 1949, Wojskowa kartografia geologiczna w okresie dwu wojen światowych. „Wiadomości Służby Topograficznej” R. 1, nr 1/2, pp. 14-28.

Rühle E., 1972, 50 lat polskiej kartografii geologicznej. „Polski Przegląd Kartograficzny” T. 4, nr 2, pp. 58-68.

Rühle E., 1984, Przeglądowa mapa geologiczna Polski w skali 1:300 000 (wydanie A) z perspektywy 30 lat jej ukończenia. „Przegląd Geologiczny” T. 32, nr 12, pp. 632-635. 
Schiefferdecker P., Möller J., Andersch C., Elditt H., Tischler O., 1870, Bericht über die geognostischen Untersuchungen der Provinz Preußen dem Hohen Landtage der Provinz Preußen übereicht von der Königl. physikalisch-ökonomischen Gesellsaft zu Königsberg, Königsberg.

Skoczylas J., 2009, Polska kartografia geologiczna w XX-leciu międzywojennym. „Przegląd Geologiczny” T. 57, nr 5, pp. 369-374.

Sokołowska M. 1954, Bibliografia kartografii geologicznej Polski. Warszawa: Instytut Geologiczny, $31 \mathrm{pp}$.

Stackebrandt W., 2005, Can geological surveys have their own standards? Some personal remarks from inside the geological survey of Brandenburg, Germany. In: The Current Role of Geological Mapping in Geoscientes". Ed. S. Ostaficzuk, Springer, Netherlands, pp. 45- 50.

Urban H., Graniczny M., 2009, Dokonania polskich geologów w kraju i za granicą w okresie rozbiorów. „Biuletyn Państwowego Instytutu Geologicznego" Nr 433, pp. 14-34.

Uścinowicz G., Kramarska R., Kaulbarsz D., Jurys L., Frydel J., Przezdziecki P., Jegliński W., 2014, Baltic Sea coastal erosion; a case study from the Jastrzębia Góra region. "Geologos" Vol. 20, no 4, pp. 259-268.

Wagenbreth O., 1999, Geschichte der Geologie in Deutschland, Berlin.

Wołkowicz S., Wołkowicz K., Miecznik J.B, 2009, Kartografia geologiczna ziem polskich do roku 1919. Katalog wystawy. Warszawa: PIG-PIB.

Wójcik A.J., 2011, Historia nauk o Ziemi. In: „Dzieje nauki. Nauki ścisłe i przyrodnicze”. Warszawa-Bielsko-Biała: Wydawnictwo Szkolne PWN, pp. 305-389.

Wójcik A.J., 2013, Carta Geologica. Mapy geologiczne Królestwa Polskiego wydane w latach 1815-1915. Dąbrowa Górnicza: Muzeum Miejskie „Sztygarka”.

Wójcik Z., 1992, Znajomość ważniejszych kopalin na ziemiach polskich w epoce Oświecenia. „Kwartalnik Historii Nauki i Techniki" T. 37, nr 2, pp. 33-66.

Zawadzka-Kahlau E., 1999, Tendencje rozwojowe polskich brzegów południowego Bałtyku. Gdańsk: Gdańskie Towarzystwo Naukowe, 147 pp.

\section{Cartographic sources}

Hasemann J., 1940, Geologische Karte des Deutschen Reiches, Blatt Belgard. Berlin: Reichsstelle für Bodenforschung.

Keilhack K., 1930, Geologische Karte der Provinz Pommern und der anschliessenden Teile der Grenzmark. Berlin: Preussische Geologische Landesanstalt.

Mojski J.E., 1959, Szczegółowa mapa geologiczna Polski w skali 1:50 000, arkusz Polanów. Warszawa: Instytut Geologiczny.

Tyski S, 1960, Szczegółowa mapa geologiczna Polski w skali 1:50 000, arkusz Białogard. Warszawa: Instytut Geologiczny.

Zeise O. 1903a, Geologische Spezialkarte von Preußen und den Thüringischen Staaten. Maßstab 1:25 000. Blatt Danzig. Berlin: Königlich Preussische Geologische Landesanstalt und Bergakadademie.

Zeise O. 1903b, Geologische Spezialkarte von Preußen und den Thüringischen Staaten. Maßstab 1:25 000. Blatt Oliva. Berlin: Königlich Preussische Geologische Landesanstalt und Bergakadademie.

Zeise O. 1903c, Geologische Spezialkarte von Preußen und den Thüringischen Staaten. Maßstab 1:25 000. Blatt Weichselmünde mit Neufahrwasser. Berlin: Königlich Preussische Geologische Landesanstalt und Bergakadademie.

Zeise O., Wolff W. 1916, Geologische Karte von Preußen und benachbarten Bundesstaaten. Maßstab 1:25 000. Blatt Danzig. Berlin: Königlich Preussische Geologische Landesanstalt.

\section{Internet sources}

http://mapy.amzp.pl/ (access 18.12.2016)

https://www.britannica.com (access 18.12.2016)

http://www.davidrumsey.com/ (access 18.12.2016)

http://www.deutsche-biographie.de/ (access 18.12.2016)

http://geoportal.pgi.gov.pl/ (access 18.12.2016)

http://www.mapy.eksploracja.pl/ (access 18.12.2016)

http://www.staremapy.org/ (access 18.12.2016)

http://www.trojmiasto.pl/ (access 18.12.2016) 